\title{
Application of mitogen-activated protein kinase inhibitor SP 600125 for wound healing control
}

\author{
Irina A Shurygina ${ }^{1,2^{*}}$, Michael G Shurygin ${ }^{1,2+}$, Galina B Granina ${ }^{1 \dagger}$ and Nikolay V Zelenin ${ }^{1 \dagger}$ \\ ${ }^{*}$ Correspondence: irinashurygina@gmail.com \\ ${ }^{\dagger}$ These authors contributed equally to this work. \\ 'Scientific Center of Reconstructive and Restorative Surgery SB RAMS, Irkutsk, Russia. \\ ${ }^{2}$ Irkutsk Scientific Center SB RAS, Irkutsk, Russia.
}

\begin{abstract}
Background: The problem of wound healing remains critical due to lack of methods for direct control of regeneration processes.

Main purpose of the study: To investigate the ability to control wound healing process by inhibiting JNK mitogenactivated protein kinase.

Methods: Skin-muscle wounds were made to Wistar rats 9 months old, 220-250 g weight. Two groups were examined, each one consisted of 30 animals: control group (inoculation of placebo plate); JNK group (inoculation of the inhibitor of JNK MAPK cascade SP 600125, the dosage per one animal was $2,6 \mu \mathrm{g} / \mathrm{kg}$ delivered in the form of original medicated film). The animals were taken out of the experiment in the periods from 2 hours up to 30 days. The segments of the skin-muscle wound were subjected to histological, immunohistochemical (staining for Col1A1, actin, CD34) and immunofluorescent (staining for CD34, CD45, MMP9) investigations. We measured the ratio of section area occupied by collagen fibers to the total area of tissue in micrographs our proposed method. The analysis of the contingence tables and Mann-Whitney $U$ test were used during the investigation.

Results: The study revealed that application of JNK MAPK inhibitor alters the wound healing process considerably, stimulates early generation of connective tissue, increases its production rate and accelerates maturation of connective tissue in the wound area. Application of JNK MAPK inhibitor impacts considerably marker expression of various fibroblasts, causing higher expression of their marrow precursors in the focus, which is indicative of more active attraction of progenitor cells into the connective tissue generation zone. Early application of JNK MAPK inhibitor increases quantity of myofibroblasts in the wound and increases expression of procollagen in fibroblasts located in the zone of connective tissue formation. The risk of keloid scarring remains small because there is an early completion of the scar formation and in this area there no cells that are capable for prolonged intensive collagen synthesis. The results enable to consider local inhibition of JNK MAPK cascade associated with a wound process to be a prospective approach to acceleration of surgical wound healing.

Conclusions: It has thus been established that the application of MAPK inhibitor considerably affects marker expression of various fibroblasts, which increases the expression of marrow precursors in the focus, being indicative of a more active attraction of progenitor cells into connective tissue formation zone. The developed original method of local application of JNK MAPK inhibitor SP 600125 to surgical wound, which enables to modify the surgical wound healing process with a single application, is recommended for pre-clinical and clinical trials for further wide clinical application.
\end{abstract}

Keywords: Connective tissue, JNK mitogen-activated protein kinases, wounds and injuries

\section{Background}

The problem of wound healing optimization remains critical due to lack of methods of direct control over regeneration processes. Millions of patients are operated in hospitals around the world every year, whereas the postoperative period is often complicated by regeneration disturbance in the surgical wound area. Apart from extended healing duration, this causes the development of certain complications [1].

One of particular complications during the postoperative period is discrepancy related to healing problems. According to M.K. Cigdem et al., [2] discrepancy accounts for $0.2-1.2 \%$ of all complications in early post-operative period. This problem may have numerous causes. Aside from problems related with wound contamination or surgical errors ((eruption of surgical sutures) (29\%), infection (13\%), combination of eruption of surgical sutures and infection (5\%), as well as defects in surgical technique, e.g., suture defects (10\%), loose knots (5\%) [1], the definite cause of discrepancy may not be detected in $48 \%$ of all cases [1], which suggests presence of endogenic disorders of wound healing process. It is also known that certain conditions, such as diabetes, atherosclerosis, obesity may aggravate the surgical wound healing process considerably vs. normal [3-5]. However, the exact cause of that currently remains unknown.

C 2013 Shurygina et al; licensee Herbert Publications Ltd. This is an Open Access article distributed under the terms of Creative Commons Attribution License (http://creativecommons.org/licenses/by/3.0). This permits unrestricted use, distribution, and reproduction in any medium, provided the original work is properly cited. 
The discovery of Mitogen-Activated Protein Kinase (MAPK) as universal cascade mechanisms involved in implementation of all stages of wound process enabled to put forward the hypothesis that surgical wound healing process may be controlled by altering the activity of c-Jun $\mathrm{N}$-terminal kinases (JNK) MAPK-one of the key elements in the process of cell differentiation, inflammation and apoptosis [6].

c-Jun N-terminal kinases are activated by cytokines, UV light, heat and osmotic shock [7]. JNK group control inhibition of cell growth and inflammatory reactions [8-12]. Main purpose of the study: to investigate the ability to control wound healing process by inhibiting JNK mitogenactivated protein kinase.

\section{Materials and methods}

Skin-muscle wounds were made to Wistar rats 9 months old, 220-250 g weight. The experiment was carried out under the "The Guide for the Care and Use of Laboratory Animals" as per the record approved by the Local Committee of Biomedical Ethics of Scientific Center of Reconstructive and Restorative Surgery SB RAMS.

The rats were sedated by ketamine $25 \mathrm{mg} / \mathrm{kg}$, droperidol $1.25 \mathrm{mg} / \mathrm{kg}$ and atropine $0.2 \mathrm{mg} / \mathrm{kg}$. The wounds were made paravertebral on the chest area $5 \mathrm{~cm}$ in length. Then a perforated plate with the tested material with the slow resorption of the active ingredient as have been developed (control group-placebo plate) was inserted into the wound. Five surgical sutures were made at the equal distance. Two groups were examined, each one consisted of 30 animals: control group (inoculation of placebo plate); JNK group (inoculation of the inhibitor of JNK MAPK cascade SP 600125 (Tocris bioscience, cat No 1496 Bath No7 A/B 1710) the dosage per one animal was $2,6 \mu \mathrm{g} / \mathrm{kg}$ ). The calculation of the medication dosage was carried out according to IC50 [13-16].

Solution of active substance was inoculated slowly (over 3 days) by means of resorbable medicated film of our own development $[17,18]$.

The animals were taken out of the experiment in the periods from 2 hours up to 30 days. The segments of the skin-muscle wound were fixed by FineFix (Milestone, Italy), embedded into paraffin for histological, immunohistochemical and immunofluorescent investigations.

The immunohistochemical investigation was made with the help of Novocastra kit (Novocastra). We used Col 1A1 (D-13) goat polyclonal lgG (Santa Cruz, Cat. N Sc-25974, Lot \# BO310), dilution 1:300; Actin (Pan) Rabbit Monoclonal Antibody (Epitomics, Cat. N 1844-1, Lot D 091805), dilution 1:200, CD34 (ICO 115) mouse monoclonal lgG (Santa Cruz, Cat. N Sc-7324, Lot \# C 0909), dilution 1:300 as primary antibodies.

Antibodies used as primary antibodies in immunofluorescent investigation included the following: antibodies to CD34 (ICO 115) mouse monoclonal IgG (Santa Cruz, Cat. N Sc-7324, Lot \# C 0909), applied dilution 1:300; antibodies to
CD45 (OX 30) mouse monoclonal lgG 2a (Santa Cruz, Cat. N Sc-53047, Lot \#B 2409), applied dilution 1:300; antibodies to MMP9 rabbit monoclonal antibody IgG (Epitomics, Clone 1D : EP1254, Cat. N 2551-1, Lot YG 113001P), applied dilution 1:200. Secondary antibodies used included the following: Alexa fluor 488 goat anti-mouse lgG $(\mathrm{H}+\mathrm{L})$ (Invitrogen, Cat. N A-11029, Lot 898236), applied dilution 1:300; Alexa fluor 488 goat anti-rabbit lgG $(\mathrm{H}+\mathrm{L})$ (Invitrogen, Cat. N 11034, Lot 870976), applied dilution 1:300, Alexa fluor 568 goat anti-mouse IgG $(\mathrm{H}+\mathrm{L})$ (Invitrogen, Cat. N A-11031, Lot 822389), applied dilution 1:300.

Nucleus counterstaining by DAPI (Biotium, Cat. N 40011, Lot 8D 0605), applied dilution 1:50. Finally coverslip was attached to slides with Fluoromount medium (Diagnostic Biosystems, REF K024, Lot P 939-B).

Specific luminance of fluorochromes was visualized with investigation microscope Nikon Eclipse $80 \mathrm{i}$, with an epifluorescence attachment DIH-M. Filters used to isolate the required fluorescence ranges included the following: Nikon DAPI (325-375 nm, dichroic mirror 400 LP, emission 435-485 nm), Nikon B-2A (excitation 450-490 nm, dichroic mirror 505 LP, emission $\geq 515 \mathrm{~nm}$ ), Nikon TRITC (excitation 528-553 nm, dichroic mirror 565 LP, emission 590-650 nm). Nikon DS-Fi1c camera connected to Nikon DS-U2 controller was used to record the images with application of Nikon Elements software. Channel convergence was performed in ImageJ software (NIH, USA) using Stacks-Multi-D plugin.

To assess the collagen fibers in connective tissue, we measured the ratio of section area occupied by collagen fibers to the total area of tissue on micrographs of tissue sections stained by Van Gieson's, as our own method [19].

The analysis of the contingence tables and MannWhitney $U$ test were used during the investigation [20]. The critical level of the criteria relevance was equal to 0.05 . The analysis of the data was carried out using the statistical package r-project.

\section{Results}

The effect of JNK MAPK SP 600125 inhibitor onto healing process of a surgical wound was investigated. The study determined that in control group of animals the process of connective tissue formation in place of skin-muscle wound corresponded to classic development pattern of inflammatory process as a response to damage in aseptic conditions. Apparent edema of dermis and subcutaneous tissue as well as initial neutrophilic infiltration were observed already after 2 hours after modeling of the wound. At 12 hours after the wounding, both edema and infiltration increased and reached the peak of the entire observation period. After 1 day since the start of experiment, intensity of edema and infiltration reduced slightly. Formation of granulation tissue predictably began since the $3^{\text {rd }}$ day of experiment. Enlargement zone of immature connective tissue and density of fibroblastic cell elements were increasing toward the $7^{\text {th }}$ day of experiment. On the $14^{\text {th }}$ 


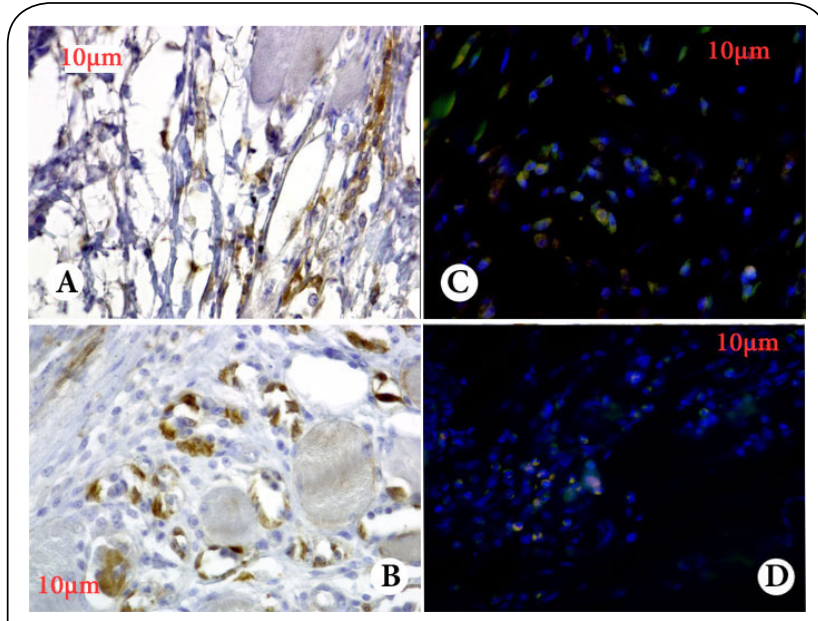

Figure 1. Expression of progenitor cells markers in the zone of connective tissue formation.

A. Control group, 3 days. Expression of CD34+ markers by cells in the zone of connective tissue formation (brown). Immunohistochemical analysis, primary antibodiesCD34 (Santa cruz), 1:300, nucleuses were stained with haematoxylin. Scale bars $=10 \mu \mathrm{m}$.

B. JNK group, 3 days. Intense expression of CD34+ markers by fibroblasts and endothelial cells in the zone of connective tissue formation (brown). Immunohistochemical analysis, primary antibodies-CD34 (Santa cruz), 1:300, nucleuses were stained with haematoxylin. Scale bars $=10 \mu \mathrm{m}$.

C. Control group, 7 days. Co-expression of CD34+ CD45+ markers by cells in the zone of connective tissue formation. Immunofluorescence, primary antibodies-CD34 (Santa cruz), 1:300, secondary antibodies-Alexa Fluor 488 (green), primary antibodies-CD45 (Santa cruz), 1:300, secondary antibodies - Alexa Fluor 568 (red), nucleuses were stained with DAPI (blue). Scale bars $=10 \mu \mathrm{m}$.

D. JNK group, 3 days. Co-expression of CD34+

CD 45+ markers by cells in the zone of surgical wound. Immunofluorescence, primary antibodies-CD34 (Santa cruz), 1:300, secondary antibodies-Alexa Fluor 488 (green), primary antibodies-CD45 (Santa cruz), 1:300, secondary antibodies-Alexa Fluor 568 (red), nucleuses were stained with DAPI (blue). Scale bars $=10 \mu \mathrm{m}$.

day, complete epithelialization of the wound was observed, and maturation of newly generated connective tissue began. Density of fibroblasts in the wound area was on the decline on the $30^{\text {th }}$ day of experiment. A wide and pronounced scar was forming.

A different development pattern was observed in animals inoculated with JNK MAPK SP 600125 inhibitor. Start of neutrophilic reaction was observed in 2 hours after the start of experiment. After 12 hours elapsed, expression of neutrophilic infiltration was growing, although edema was virtually absent. Neutrophilic reaction in the damaged zone reached its peak expression after 1 day since infliction of the wound. Apparent enlargement of immature connective tissue with expressed extracellular collagen deposits in the damaged zone was observed in animals of this group already on the $3^{\text {rd }}$ day of the experiment. A clear and apparent scar was formed in 7 days. Further maturation of scar occurred over the remainder of time.

Meanwhile, width of the scar formed at the end of observation period (on the $30^{\text {th }}$ day) remained similar to that within the control group (JNK - 573.67 [311.10-1450.84] $\mathrm{mkm}$, control group - 763.47 [334.1-1285.31] mkm, Z=0.166 $\mathrm{p}=0.869$ ).

It was determined in the course of investigation that relative volume of collagen in the post-operative scar formation zone in control group of animals was increasing since the $3^{\text {rd }}$ till the $30^{\text {th }}$ day of the experiment, predictably reaching its peak on the $30^{\text {th }}$ day of observation (median value of $73.54 \%, 25-75 \%$ quartiles $66.87 \%-78.01 \%$ ). Concentration of collagen in the zone of intact dermis has not demonstrated meaningful changes over the period of observation. Credible increase of collagen concentration by the $14^{\text {th }}$ day $(p=0.029)$ was observed in derma only in proximity of the wound.

Intensity of collagen generation in the area of surgical wound increased considerably after application of with JNK MAPK SP 600125 inhibitor. In particular, already on the $3^{\text {rd }}$ day of the wound process, the amount of collagen surpassed the respective value of control group by 4 times (median value 44.44 [23.26-70.30] and 11.57 [8.53-27.85] accordingly, $z=4.00, p=0.00063)$. Eventually, at the end of observation period ( $30^{\text {th }}$ day of experiment), density of collagen in the experimental group was higher than in control group (median value 78.14 [72.77-81.14] and 73.54 [66.87-78.01] accordingly, $z=2.29, p=0.0219$ ). Alongside with that, application of SP 600125 has not produced any considerable effect onto concentration of collagen neither in intact dermis, nor the zone in wound proximity.

In order to assess the effect of JNK MAPK inhibitors onto differentiation of fibroblasts in the focus of connective tissue formation, we investigated expression of marroworiginated cell markers (CD34), white blood cell markers (CD45), procollagen of type I (CollAI), MMP9, as well as actin in fibroblasts at the wound healing zone.

It has been determined that CD34+ was expressed in the area of scar formation in control group of animals on the $3^{\text {rd }}$ day of the wound process (Figure 1A), while faint staining of only a few cells in the wound zone was observed on the $7^{\text {th }}$ day. No specific staining was observed at other terms.

At the same time, application of JNK inhibitor caused a rapid increase of CD34+ cells in the area of the wound. In particular, individual CD34+ cells were observed already after 12 hours of the wound process modeling start. The number of these cells increased rapidly up to the $3^{\text {rd }}$ day (Figure 1B), whereas not only fibroblasts were stained, but also endotheliocytes of new vessels, which is an indirect indication of angiogenesis activation. Numerous fibroblasts bearing CD34+ markers remained in scar forming area for the period of up to 7 days.

Co-expression of CD34+CD45+, which is indicative of presence of marrow-derived fibroblast progenitors in 


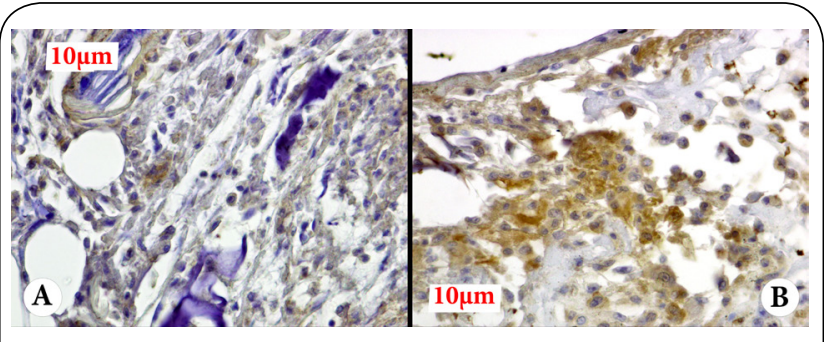

Figure 2. Myofibroblasts in the zone of connective tissue formation.

A. Control, 3 days. Individual myofibroblasts in the zone of surgical wound (brown). Immunohistochemical analysis, primary antibodies to actin (Epitomics), 1:200, nucleuses were stained with haematoxylin. Scale bars $=10 \mu \mathrm{m}$.

B. JNK group, 3 days. Enormous quantity of myofibroblasts in the zone of connective tissue formation (brown). Immunohistochemical staining, primary antibodies to actin (Epitomics), 1:200, nucleuses were stained with haematoxylin. Scale bars $=10 \mu \mathrm{m}$.

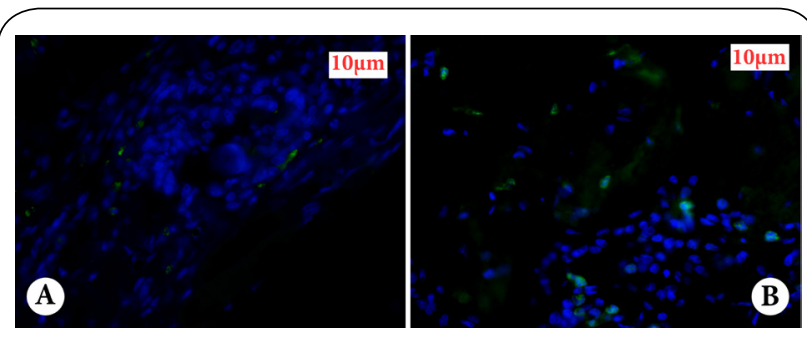

Figure 3. Expression of MMP9 in the zone of connective tissue formation.

A. Control, 7 days. Individual fibroblasts expressing MMP9 in the zone of connective tissue formation. Immunofluorescence, primary antibodies to MMP9 (Epitomics), 1:200, secondary antibodies-Alexa Fluor 488 (green), nucleuses were stained with DAPI (blue). Scale bars $=10 \mu \mathrm{m}$.

B. JNK group, 7 days. Individual fibroblasts expressing MMP9 in the zone of connective tissue formation. Immunofluorescence, primary antibodies to MMP9 (Epitomics), 1:200, secondary antibodies-Alexa Fluor 488 (green), nucleuses were stained with DAPI (blue). Scale bars $=10 \mu \mathrm{m}$.

the focus, was only registered in control group on the $7^{\text {th }}$ day (Figure 1C).

When JNK inhibitor was applied, early appearance of progenitor cells was observed in regeneration zone-on the $3^{\text {rd }}$ day after modeling of skin-muscle wound (Figure 1D). No progenitor cells were discovered in the regeneration zone at later observation points.

In order to evaluate presence of myofibroblasts in the area of connective tissue formation, the method of actin staining was used, which allows to differentiate these cells [21]. We determined that moderate number of stained cells was observed in control group on the $3^{\text {rd }}$ and $7^{\text {th }}$ day of wound process (Figure 2A).

At the same time, when JNK inhibitor was used, staining of individual cells for actin was observed starting with 12 hours of the wound process. Staining remained for up to 7 days, whereas an enormous number of stained cells was observed on the $3^{\text {rd }}$ and $7^{\text {th }}$ days (Figure 2B), which indicates at numerous presence of myofibroblasts in the wound and potentially high capacity for collagen production in the wound healing zone). Lack of myofibroblasts in the wound at later periods of the wound process indicates at completion of restorative process and lack of potential for formation of keloid scar [22].

When stained for Col IAI, which enables to identify procollagen of I type in fibroblasts, only individual positively stained cells were identified in scar formation zone on the $3^{\text {rd }}$ and $7^{\text {th }}$ days in control group. In the group where JNK inhibitor was used, staining for procollagen was recorded since the $3^{\text {rd }}$ till the $14^{\text {th }}$ day, which confirms elevated synthesis activity among fibroblasts in this group of animals.

Presence of fibroblasts with collagen resorption activity in the wound, which is determined as high intensity staining on MMP9+ fibroblasts [23], was observed in the control group only on the $7^{\text {th }}$ day (Figure $3 A$ ). In JNK group, fibroblasts positive for MMP9+ were recorded as solitary cells over an extensive period - since the $3^{\text {rd }}$ till the $30^{\text {th }}$ day (Figure 3B).

\section{Discussion}

It is generally known that fibroblasts may originate from marrow precursor cells circulating in peripheral blood [24]. These fibroblast progenitors constitute approximately $0.05 \%$ of peripheral blood cells [25-26]. Their amount may increase in response to effect of certain cytokines and chemokines, as well as during inflammation or fibrosis development [27]. Fibroblast progenitors emerge from blood stream into damaged areas, and are required for formation of granulomas, scars, as well as tissue remodeling [28].

Fibroblast progenitors may have markers of white blood cells (CD45+, LSP-1), as well as monocytes (CD11a+, CD11b+, CD13+, CD32+, CD64+) and progenitor cells (CD34+, CD105+), and they also express products, which are associated with fibroblasts (type I collagen, fibronectin, vimentin, MMP9), and it is precisely the combination of CD34+ and CD45+ that enables identification of these progenitor cells during regeneration with replacement of damaged tissues by a connective tissue [23].

The study revealed that application of JNK MAPK inhibitor affects the wound healing process considerably, stimulates early connective tissue formation, increases collagen production rate and accelerates maturation of connective tissue in the wound area.

Early completion of scar formation and lack of cells in this area that capable of prolonged increased secretion of collagen allows suggesting that high risk of keloid scar formation does not exist. The accomplished results enable 
to consider local inhibition of JNK MAPK cascade associated with a wound process to be a prospective approach to acceleration of surgical wound healing.

For instance, application of JNK inhibitor as component of surgical suture may discover totally new prospects for creation of a new generation of surgical suture and mesh. It is also apparent that increase of scar strength is capable of promoting faster rehabilitation, shorter hospitalization time and temporary incapacity to work.

\section{Conclusions}

It has thus been established that application of MAPK inhibitor considerably affects marker expression of various fibroblasts, which increases expression of marrow precursors in the focus, being indicative of a more active attraction of progenitor cells into connective tissue formation zone. Application of this inhibitor increases the number of myofibroblasts in the wound at early periods and elevates expression of procollagen in fibroblasts, which indicates at increased functional activity of these cells in the scar formation zone.

The developed original method of local application of JNK MPAK inhibitor SP 600125 to surgical wound, which enables to modify the surgical wound healing process with a single application, is recommended for pre-clinical and clinical trials for further wide clinical application.

Application of JNK MAPK SP 600125 may be prospective in surgical suture, drainage and other implantable medical goods.

\section{List of abbreviations}

CD: Cluster of differentiation

Col 1A1: Collagen a1 Type I

IC50: half maximal inhibitory concentration

JNK: c-Jun N-terminal kinase

MAPK: Mitogen activated protein kinase

MMP9: Matrix metallopeptidase 9

\section{Competing interests}

The authors declare that they have no competing interests.

Authors' contributions

\begin{tabular}{|l|c|c|c|c|}
\hline Authors' contributions & IAS & MGS & GBG & NVZ \\
\hline Research concept and design & $\checkmark$ & $\checkmark$ & -- & -- \\
\hline Collection and/or assembly of data & $\checkmark$ & $\checkmark$ & $\checkmark$ & $\checkmark$ \\
\hline Data analysis and interpretation & $\checkmark$ & $\checkmark$ & -- & -- \\
\hline Writing the article & $\checkmark$ & -- & -- & -- \\
\hline Critical revision of the article & -- & $\checkmark$ & -- & -- \\
\hline Final approval of article & $\checkmark$ & $\checkmark$ & $\checkmark$ & $\checkmark$ \\
\hline Statistical analysis & -- & $\checkmark$ & -- & -- \\
\hline
\end{tabular}

Acknowledgement

This work was performed through support from Russian Academy of Medicine under Contract No 0120965321, 01201280990; and Ministry of Education and Science of the Russian Federation (ProjectNo. P803).
Publication history

Received: 21-Jun-2013 Revised: 27-Sep-2013

Accepted: 07-Oct-2013 Published: 25-Oct-2013

\section{References}

1. van Ramshorst GH, Salu NE, Bax NM, Hop WC, van Heurn E, Aronson $\mathrm{DC}$ and Lange JF. Risk factors for abdominal wound dehiscence in children: a case-control study. World J Surg. 2009; 33:1509-13. | Article | PubMed Abstract | PubMed Full Text

2. Cigdem MK, Onen A, Otcu S and Duran H. Postoperative abdominal evisceration in children: possible risk factors. Pediatr Surg Int. 2006; 22:677-80. | Article | PubMed

3. Woo K, Ayello EA and Sibbald RG. The edge effect: current therapeutic options to advance the wound edge. Adv Skin Wound Care. 2007; 20:99-117. | Article | PubMed

4. Galkowska H, Olszewski WL, Wojewodzka U, Rosinski G and Karnafel $W$. Neurogenic factors in the impaired healing of diabetic foot ulcers. J Surg Res. 2006; 134:252-8. | Article | PubMed

5. Wilson JA and Clark JJ. Obesity: impediment to postsurgical wound healing. Adv Skin Wound Care. 2004; 17:426-35. | Article I PubMed

6. Oltmanns $U$, Issa R, Sukkar MB, John M and Chung KF. Role of c-jun $\mathrm{N}$-terminal kinase in the induced release of GM-CSF, RANTES and IL-8 from human airway smooth muscle cells. Br J Pharmacol. 2003; 139:1228-34. | Article | PubMed Abstract | PubMed Full Text

7. Waetzig $V$ and Herdegen T. Context-specific inhibition of JNKs: overcoming the dilemma of protection and damage. Trends Pharmacol Sci. 2005; 26:455-61. | Article | PubMed

8. Goberdhan DC and Wilson C. JNK, cytoskeletal regulator and stress response kinase? A Drosophila perspective. Bioessays. 1998; 20:1009-19. | Article | PubMed

9. Hommes DW, Peppelenbosch MP and van Deventer SJ. Mitogen activated protein (MAP) kinase signal transduction pathways and novel anti-inflammatory targets. Gut. 2003; 52:144-51. | Article I PubMed Abstract | PubMed Full Text

10. Lee SM, Kim EJ, Suk K and Lee WH. Stimulation of Fas (CD95) induces production of pro-inflammatory mediators through ERK/JNK-dependent activation of NF-kappaB in THP-1 cells. Cell Immunol. 2011; 271:157-62. | Article | PubMed

11. Li M, Wu ZM, Yang $H$ and Huang SJ. NFkappaB and JNK/MAPK activation mediates the production of major macrophage- or dendritic cell-recruiting chemokine in human first trimester decidual cells in response to proinflammatory stimuli. J Clin Endocrinol Metab. 2011; 96:2502-11. | Article | PubMed Abstract | PubMed Full Text

12. Tsao PN, Wei SC, Huang MT, Lee MC, Chou HC, Chen CY and Hsieh WS. Lipopolysaccharide-induced Notch signaling activation through JNK-dependent pathway regulates inflammatory response. J Biomed Sci. 2011; 18:56-64. I Article I PubMed Abstract | PubMed Full Text

13. Cheng $Y$ and Prusoff WH. Relationship between the inhibition constant (K1) and the concentration of inhibitor which causes 50 per cent inhibition (150) of an enzymatic reaction. Biochem Pharmacol. 1973; 22:3099-108. | PubMed

14. Bennett BL, Sasaki DT, Murray BW, O’Leary EC, Sakata ST, Xu W, Leisten JC, Motiwala A, Pierce S, Satoh Y, Bhagwat SS, Manning AM and Anderson DW. SP600125, an anthrapyrazolone inhibitor of Jun N-terminal kinase. Proc Natl Acad Sci U S A. 2001; 98:13681-6. | Article I PubMed Abstract I PubMed Full Text

15. Bain J, McLauchlan H, Elliott M and Cohen P. The specificities of protein kinase inhibitors: an update. Biochem J. 2003; 371:199-204 | Article | PubMed Abstract | PubMed Full Text

16. Wang Y, Ji HX, Xing SH, Pei DS and Guan QH. SP600125, a selective JNK inhibitor, protects ischemic renal injury via suppressing the extrinsic pathways of apoptosis. Life Sci. 2007; 80:2067-75. | Article I PubMed

17. Shurygin MG, Shurygina IA: RU Patent, 2445074, 2012-03-20

18. Shurygina IA, Shurygin MG, Ayushinova NI, Granina GB and Zelenin 
NV. Mechanisms of connective tissue formation and blocks of mitogen activated protein kinase. Front Chem Sci Eng. 2012; 6: 232-7. I Article

19. Shurygin MG, Dremina NN, Shurygina IA, Machkhin IN, Antipina SL: RU Patent, 2332665, 2007-08-27.

20. Glantz SA and Slinker BK. Primer of applied regression and analysis of variance. 2000; 1-949. | Book

21. Powell DW. Myofibroblasts: paracrine cells important in health and disease. Trans Am Clin Climatol Assoc. 2000; 111:271-92. | PubMed Abstract I PubMed Full Text

22. Wynn TA. Common and unique mechanisms regulate fibrosis in various fibroproliferative diseases. J Clin Invest. 2007; 117:524-9. | Article | PubMed Abstract | PubMed Full Text

23. Bellini A and Mattoli S. The role of the fibrocyte, a bone marrow-derived mesenchymal progenitor, in reactive and reparative fibroses. Lab Invest. 2007; 87:858-70. | Article | PubMed

24. Bucala R, Spiegel LA, Chesney J, Hogan M and Cerami A. Circulating fibrocytes define a new leukocyte subpopulation that mediates tissue repair. Mol Med. 1994; 1:71-81. | PubMed Abstract | PubMed Full Text

25. Phillips RJ, Burdick MD, Hong K, Lutz MA, Murray LA, Xue YY, Belperio $J A$, Keane MP and Strieter RM. Circulating fibrocytes traffic to the lungs in response to CXCL12 and mediate fibrosis. J Clin Invest. 2004; 114:438-46. | Article | PubMed Abstract | PubMed Full Text

26. Quan TE, Cowper S, Wu SP, Bockenstedt LK and Bucala R. Circulating fibrocytes: collagen-secreting cells of the peripheral blood. Int $J$ Biochem Cell Biol. 2004; 36:598-606. | Article | PubMed

27. Mehrad B, Burdick MD, Zisman DA, Keane MP, Belperio JA and Strieter RM. Circulating peripheral blood fibrocytes in human fibrotic interstitial lung disease. Biochem Biophys Res Commun. 2007; 353:104-8. | Article | PubMed

28. Abe R, Donnelly SC, Peng T, Bucala R and Metz CN. Peripheral blood fibrocytes: differentiation pathway and migration to wound sites. $J$ Immunol. 2001; 166:7556-62. | Article | PubMed

\section{Citation:}

Shurygina IA, Shurygin MG, Granina GB and Zelenin NV. Application of mitogen-activated protein kinase inhibitor SP 600125 for wound healing control.

J Regen Med Tissue Eng. 2013; 2:9.

http://dx.doi.org/10.7243/2050-1218-2-9 